\title{
Food or nesting place? Identifying factors limiting Wryneck populations
}

\author{
Valérie Coudrain · Raphaël Arlettaz . \\ Michael Schaub
}

Received: 6 July 2009/Revised: 16 March 2010/Accepted: 24 March 2010/Published online: 11 April 2010

(C) Dt. Ornithologen-Gesellschaft e.V. 2010

\begin{abstract}
In recent decades, farmland bird populations have declined strongly as a consequence of agriculture intensification. Birds may have lost breeding sites, food supply or other crucial resources, with the role of multiple factors often remaining unclear. The ant-eating and cavitybreeding Wryneck (Jynx torquilla) may be limited by the availability of cavities, the number of ants or their accessibility. By comparing occupied and unoccupied breeding territories, we investigated the relative role of these factors in the decline of Wrynecks. We compared the characteristics of known Wryneck breeding territories (availability of breeding cavities, food abundance and ground vegetation structure) with randomly selected, fictitious territories $(n=154)$ in Western Switzerland. We also studied environmental factors that may affect ant nest density. The probability of territory occupancy strongly increased with both nestbox availability and ant abundance. In addition, this probability peaked around 50\% of bare ground cover. Habitat types that harbour low ant abundance such as cropland and grassland were avoided. Ant nest density decreased with increasing amounts of bare ground, and it was particularly high in vineyards. Our results showed that breeding cavities, food availability and its accessibility all limit Wryneck distribution. The maintenance and restoration of ant rich grassland, interspersed with patches of bare
\end{abstract}

Communicated by P. H. Becker.

V. Coudrain $\cdot$ R. Arlettaz $\cdot$ M. Schaub $(\square)$

Division of Conservation Biology, Institute of Ecology

and Evolution, University of Bern, Baltzerstrasse 6,

3012 Bern, Switzerland

e-mail: michael.schaub@iee.unibe.ch

R. Arlettaz $\cdot$ M. Schaub

Swiss Ornithological Institute, 6204 Sempach, Switzerland ground and with hollow trees or dedicated nestboxes in the surroundings, are essential to preserve Wryneck populations. Such a habitat structure could be achieved even in intensively farmed habitats, such as in vineyards or fruit tree plantations.

Keywords Ant nest abundance - Nest box . Vegetation structure $\cdot$ Bare ground $\cdot$ Jynx torquilla

\section{Introduction}

As a result of the intensification of agriculture, which has considerably modified the structure of most landscapes, many farmland bird populations have collapsed since the middle of the twentieth century (Donald et al. 2001; Freeman and Kirk 2001; Wretenberg et al. 2006). The disappearance of unproductive structures such as hedgerows, forest patches and isolated trees, and the decline of arthropod populations caused by systematic ploughing and increased application of fertilisers as well as pesticides, have negatively affected two key ecological factors determining the persistence of farmland birds: the availability of breeding sites and of food resources (Blanco et al. 1998; Benton et al. 2002; McCracken and Tallowin 2004). For most species, it still remains unclear which essential resources are the main cause of population collapse (Newton 2004), although their identification is a prerequisite to any population conservation action plan.

Within a breeding territory, essential resources must be available for successful reproduction. Resource availability is resource abundance modified by its accessibility. Availability is often difficult to measure accurately (Hutto 1990; Cornelius et al. 2008), and surrogates are often used. When investigating the realised ecological niche of a 
species in a given context, it is essential to understand the subtle interplay between food abundance and habitat structure because the latter may largely determine food accessibility, i.e. its actual availability. Recognising these forces directing resource exploitation patterns is crucial for developing corrective measures to conserve and restore populations of endangered species.

Here, we study the habitat requirements of Wrynecks (Jynx torquilla), a small migratory woodpecker. The Wryneck is a secondary cavity breeder that forages essentially on ground-dwelling ants taken directly from their nests (Cramp 1985; Freitag 1996, 1998). It inhabits different kinds of semi-open habitats such as orchards, parks, alluvial woods, open pine forests or vineyards, provided that the two main resources, breeding cavities and ground-dwelling ants, are available (Mermod et al. 2009). Wrynecks have undergone a strong decline in Europe (Tomialojc 1994), with habitat loss or degradation mentioned as the main causes (Hölzinger 1987).

Trees are an important component of Wryneck territories. Firstly, they can contain natural cavities, offering breeding opportunities; secondly, they are used for perch hunting, a typical foraging technique of Wrynecks (Cramp 1985; Bitz and Rohe 1993; Freitag 1998). With the intensification of agriculture, large trees have been systematically removed, and high-stem orchards, a traditional habitat of Wrynecks in many areas (Hölzinger 1987; Cramp 1985), have been widely eradicated. The decline of large trees in farmland can therefore be seen as a major factor of decline.

Ground-dwelling ants are the main prey of Wrynecks. Their availability to Wrynecks is determined by their abundance modified by their accessibility. Ant brood (larvae and pupae) is especially important because it constitutes the main resource for the nestlings (Freitag 1998). As thermophilic organisms that build long-lived sedentary nests, ground-dwelling ants rely generally on warm and stable soil surfaces. They are thus sensitive to changes and disturbances in the uppermost layer of the soil (Folgarait 1998; Kaspari 2000). Intensive agricultural practices can therefore affect ant colonies directly by mechanical soil disturbance and indirectly by fertilisation that increases vegetation density, thus reducing soil surface temperature. Both can result in a considerable decline of ant nest abundance (Folgarait 1998), potentially negatively affecting Wryneck populations. However, although the effect of land management on ant species diversity has raised much interest (Peck et al. 1998; Bromham et al. 1999; Bestelmeyer and Wiens 2001; Underwood and Fischer 2006), its effects on ant abundance have been poorly investigated.

Detection of, and access to, food resources is an important issue for many ground-foraging birds in intensive farmland (Wilson et al. 2005). Whilst Wrynecks are tolerant to the presence of tall sward, the density of vegetation cover is a major determinant of foraging site selection: Wrynecks prefer to feed at places with a vegetation cover lesser than 50\% (Kervyn and Xhardez 2006; Weisshaupt 2007). The systematic fertilisation of grassland by modern farming practices inexorably leads to a denser sward. Even though a dense ground vegetation cover does not necessarily induce a decrease in ant abundance, ant detectability and accessibility may be seriously affected.

It is largely unknown which factors have caused the large-scale population decline observed in the European Wryneck. We investigated in parallel the three main factors mentioned above: decline in the offer of breeding cavities; decline of ant abundance; and impeded access and detectability of ant nests. We compared habitat features and ant occurrence in known breeding territories, and randomly selected sites currently not occupied by Wrynecks, with the aim of identifying the relative contribution of the above factors. Additionally, we studied abundance of ants in various habitat types and determined environmental factors affecting their nest density and size. This information will be useful for developing sound conservation action plans for this regionally endangered bird species.

\section{Methods}

The study was conducted from May to August 2008 in three viticultural regions of Switzerland where Wrynecks still occur in reasonable numbers. The first two regions (Neuchâtel, $47.0^{\circ} \mathrm{N}, 6.8^{\circ} \mathrm{E}, 450 \mathrm{~m}$ asl and La Côte, $46.5^{\circ} \mathrm{N}$, $6.5^{\circ} \mathrm{E}, 510 \mathrm{~m}$ asl) are situated along the northern banks of the Lakes Neuchâtel and Geneva, respectively. The third region (Geneva, $46.2^{\circ} \mathrm{N}, 6.0^{\circ} \mathrm{E}, 370 \mathrm{~m}$ asl) is located in the countryside west of the city of Geneva (Fig. 1). All regions, characterised by the proximate presence of a lake,

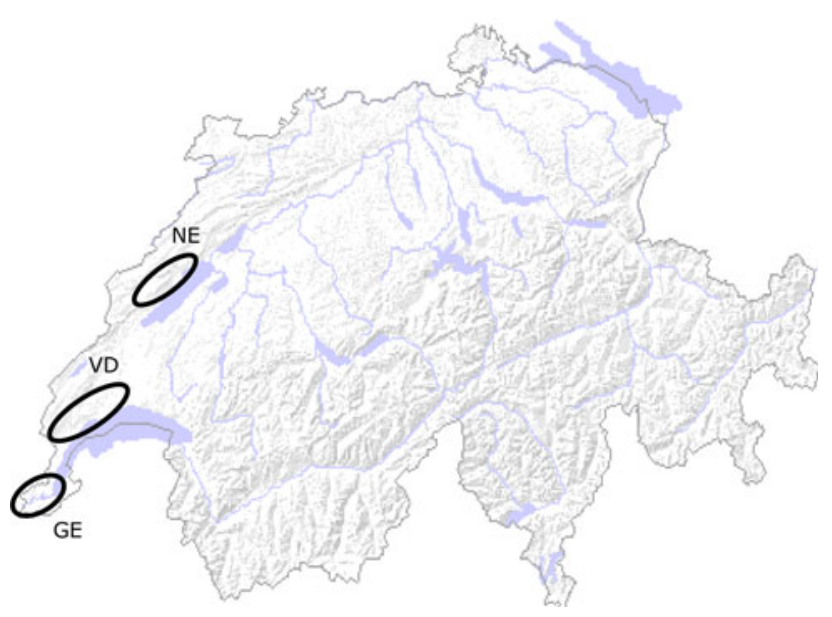

Fig. 1 Location of the three study regions within Switzerland. NE Neuchâtel, VD La Côte, GE Genève 
harbour a favourable climate allowing wine production and, especially in La Côte, fruit tree plantations. The study area is therefore intensively managed farmland. Measurements of temperatures ( $5 \mathrm{~cm}$ above ground) were obtained from the three nearest meteorological stations (Neuchâtel, Pully, Genève-Cointrin; MeteoSchweiz).

\section{Habitat requirements of Wrynecks}

\section{Sampling design}

By comparing currently occupied Wryneck territories with randomly selected, non-occupied sites, we aimed to characterise habitat preferences of Wrynecks. Based on average home-range sizes as revealed by radio tracking (Weisshaupt 2007), territories were defined as a circle with $111 \mathrm{~m}$ radius around a point location (nesting site in case of occupied territories). Actually occupied territories were obtained from nestbox surveys $(n=4$ in Neuchâtel, $n=19$ in La Côte) and casual observations during the breeding period ( $n=4$ in Neuchâtel, $n=10$ in La Côte, $n=8$ in Geneva) from the years 2006 and 2007, as well as from observations collected during territory mapping in 2008 (see below). To determine non-occupied sites, we generated for each region points at random $(n=31$ in Neuchâtel, $n=52$ in La Côte, $n=36$ in Geneva) within the minimal convex polygon defined by all occupied sites in a given region. We excluded forests, lakes and urbanised areas as random locations, because these are unsuitable habitats.

In each site initially classified as unoccupied, we checked for the presence of Wrynecks in May and June 2008 by playing back their song twice during $1 \mathrm{~min}$. Wrynecks react very strongly to songs of conspecifics, rendering the playback of their songs a reliable method to assess territory occupancy. The random sites in which the presence of the Wryneck was actually assessed were reclassified as "occupied territories" ( $n=7$ in Neuchâtel, $n=11$ in La Côte). Thus, we compared territories that have been occupied at least once from 2006 to 2008 with randomly selected sites that were not occupied in 2008 . Hereafter, we name territories and sites as occupied and unoccupied territories, respectively. In total, the study is based on 154 territories (53 occupied, 101 unoccupied; 39 in Neuchâtel, 71 in La Côte, 44 in Geneva).

\section{Habitat mapping}

We mapped habitats within all territories at the scale of parcels (fields with a given culture type that are separated from any other culture types) with the aid of geo-referenced aerial photographs. This ensured accurate mapping. We allocated all parcels to one of seven habitat types (fruit tree plantation, semi-vegetated vineyard, non-vegetated vineyard, crop, meadow, pasture, and lawn; see Appendix 1 for their definition) and recorded the amount of bare ground and vegetation height in each parcel. A territory was thus composed of a number of parcels, each parcel being defined by a habitat type, an estimated vegetation height and an estimated amount of bare ground. In several freshly cut meadows, identification of intensity of management was not possible. As a consequence, categories for meadow management intensity were only considered for the modelling of ant nest abundance. We also noted the number of nestboxes and trees (diameter at breast height $>20 \mathrm{~cm}$ ) outside forests. Habitat heterogeneity has generally a positive effect on farmland biodiversity (Benton et al. 2003); it also plays a major role in Wryneck habitat selection (Mermod et al. 2009). We defined heterogeneity as the number of parcels within a territory. Although Wrynecks do not occur in dense forests, they may use trees along forest edges or in hedges to breed. As hedges and forest edges are often more extensively managed than nearby farmland, they may provide good foraging opportunities (Poeplau 2005). We accounted for this possibility by including the variable "edge length", which combines the total length of both forest border and hedges within a territory. Field maps were digitised and the size of the parcels was measured in ArcMap (ArcGIS Version 9.2).

\section{Food resources}

Our goal was to get an estimate of the density of ant nests for each territory in order to test whether food supply was a limiting factor. We estimated habitat-specific ant densities and extrapolated this information across habitat types for the whole territory.

\section{Statistical analyses}

To compare occupied with unoccupied territories, we separately analysed two sets of explanatory variables. The first set included structural variables (amount of bare ground and its square, number of ant nests, edge length, heterogeneity, number of nestboxes and trees). The second set of variables contained the proportion of the seven different habitat types within the territories. We performed two separate analyses due to the different nature of the variables and because of some overlap in the information embedded by the two variable sets (habitat type already contains information about habitat structure).

Using the structural variables, we could test our main hypotheses. First, if food resources limit Wryneck distribution we expect an effect of ant nest numbers on occupancy. Second, if access to food limits Wryneck distribution we expect a higher amount of bare ground in occupied 
territories. Likewise, third, if Wrynecks are limited by breeding sites, we expect a positive effect of nestboxes or trees on occupancy. Using the habitat types, we could additionally test which habitat types are most profitable, which would facilitate strategic choices for habitat management.

The variables as defined above were fixed terms while the region (3 levels) was a random factor. The inclusion of a random effect for region ensured to correct for possible data non-independence. The modelling procedure was conducted using generalised linear mixed models with a binomial error distribution. We defined 64 candidate models with all possible combinations of the structural variables and 128 candidate models with all possible combinations of habitat types. We did not consider interactions.

\section{Ant abundance modelling}

\section{Sampling design}

We assumed that ant nest density is homogeneous within habitat type but affected by the amount of bare ground (Mermod et al. 2009). We therefore sampled ant nests in the different habitat types in a random subset of occupied and unoccupied Wryneck territories. In each considered territory, we selected one to several habitat types at random, where ant sampling took place. A total of 235 locations were sampled. The number of sampling locations in the different habitat types is given in Appendix 2.

At each sampling location, we searched for ant nests in five $2-\mathrm{m}^{2}$ replicates by scraping the soil with a small rake during $7 \mathrm{~min}$. The location of the five replicates was defined by selecting the first location at random, with the four others placed at $10 \mathrm{~m}$ distance from that point in each main azimuth direction. We recorded the number of nests, the amount of bare ground, and vegetation height for each replicate. For each nest, we noted its diameter (nest size) and presence of breeding activity (winged ants, larvae and pupae). We collected few individuals from each nest for subsequent species determination.

\section{Ant nest detection probability}

Because the detection of ant nests is unlikely to be perfect (Mermod et al. 2009), we estimated in a further study ant nest detection probability to correct the raw counts accordingly. We repeatedly sampled $362-\mathrm{m}^{2}$ plots in semivegetated vineyards randomly distributed in the region $\mathrm{La}$ Côte. All sampling plots were visited 3 times with a gap of 1 week between visits. We recorded the number of nests, the amount of bare ground, and the vegetation height. Some ants were collected from the detected nests.
The detection histories (a row of three numbers representing the number of recorded ant nest at each of the three visits for each plot) were analysed with a binomial mixture model (Royle and Nichols 2003) using program PRESENCE (Hines 2006). The detection probability ( $p$ ) of an ant nest at temperature $T$, amount of bare ground $b$ and vegetation height $v$ was modelled as $\operatorname{logit}\left(p_{T, b, v}\right)=\beta_{0}+$ $\beta_{1} T+\beta_{2} b+\beta_{3} v$, where the $\beta$ are parameters to be estimated.

As Wrynecks prey on the most abundant ant species (Bitz and Rohe 1993; Freitag 1998), we did not distinguish between different species. We defined eight candidate models comprising all possible combinations of the factors $T, b$ and $v$. The density, the other parameter type in the binomial mixture model, was always kept constant. This seems reasonable since we sampled ants only in one homogenous habitat.

\section{Predicting ant abundance for each parcel}

Our goal was to estimate the abundance of ant nests at the Wryneck breeding territory scale by extrapolating the ant nest density to the complete territory surface. To account for imperfect detection, we corrected the raw counts $\left(C_{i}\right)$ from any replicate $i$ with temperature $T$, bare ground $b$ and vegetation height $v$ as $\hat{N}_{i}=C_{i} / \hat{p}_{T, b, v}$. We then modelled the corrected ant nest counts $(\hat{N})$ in relation to habitat type, bare ground and its square through a generalised linear mixed model with a Poisson error distribution. The habitat type "crop" was not included in the analysis because only two ant nests have been found in this habitat (28 locations sampled), suggesting that ant nest density was very close to 0 .

The sampling location (group of five replicates) was treated as random variable to account for possible dependence. We defined eight candidate models comprising all possible combinations of the fixed effect variables and the interaction between amount of bare ground and habitat type to test whether the relationship between bare ground and abundance was the same in each habitat type. The parameter estimates of the best model were used to calculate the ant nest densities in function of identified variables for each parcel. The obtained density (nests $/ \mathrm{m}^{2}$ ) was multiplied by the size of the corresponding parcel to obtain an estimate of the number of nests.

\section{Variables affecting ant nest density and size}

As ant nest density, size and content are assumed to determine food abundance for Wrynecks, we identified the main environmental variables affecting them. To determine the variables affecting ant nest density, we applied the same models as described above to which we added the 
fixed variable "Wryneck presence" that indicates whether the sampling location was within an occupied or unoccupied territory. This allowed testing in addition whether ant nest densities were consistently higher where Wrynecks occurred. In total, we formulated 19 candidate models comprising all possible combinations of the fixed effect variables and the interaction between bare ground and habitat type, and between Wryneck presence and habitat type.

To assess the potential impact of grassland management on ant nest density, we modelled ant nest density in relation to meadow type, where the latter could be accurately determined. As fixed effect variables, we included meadow type, amount of bare ground and its square, and we treated sampling plots as random factor. We defined six candidate models comprising all possible combinations of the fixed effect variables.

To analyse the relationship between ant nest size and environmental variables, we used generalised linear mixed models with a normal error distribution. As fixed variables we included amount of bare ground, habitat type, temperature and its square. Temperature was included because ants are expected to move deeper into the soil at low or very high temperatures (Freitag 1998), resulting in apparent smaller nests. We considered the same habitat types as for ant nest density modelling but could also include nonvegetated vineyards, because the sample size for this habitat type was large enough. To account for possible data interdependence of nests close to each other, we considered replicates nested in sampling locations as random variables. We defined 14 candidate models comprising all possible combinations of the fixed effect variables.

As ant brood is an energy-rich resource for nestlings, we performed a regression analysis between the presence of ant brood (presence of new queens, larvae or pupae in the nest) and the size of the nests using generalised linear mixed models with a binomial error distribution. The ant species was included as a random factor.

\section{Ant species determination}

The collected ants were inspected with a binocular microscope. The determination was carried out to the species level or to the family level if uncertainty was too high, using the identification keys of Della Santa (1994) and Seifert (1996).

Model selection and predictions

For all modelling procedures described above, the candidate models were ranked according to their AIC (Aikaike's Information Criterion). The AIC is composed of the model deviance and the number of estimated parameters and thus allows ranking different models according to the best compromise between precision and bias (Burnham and Anderson 2002). Since there was uncertainty in model selection, we considered models within $\triangle \mathrm{AIC}<2$, and averaged their predictions using standardised AIC weights. Predictions and confidence intervals from single models were obtained with non-parametric bootstrapping $(1,000$ replicates). All modelling procedures were conducted in $\mathrm{R}$ 2.7.1 with function (lmer) (R Development Core Team).

\section{Results}

Ant abundance modelling

\section{Ant diversity}

We detected 2,101 ant nests belonging to eight species. Lasius niger was in all regions the most abundant species (38.9\%, $n=818)$. Solenopsis fugax (21\%, $n=442)$, Tetramorium caespitum $(18.6 \%, n=391)$ and Lasius flavus $(11.1 \%, n=234)$ were also common and widely distributed. Myrmica spp. $(6.1 \%, n=128)$, Tapinoma erraticum (2.2\%, $n=47)$, Formica spp. (1.7\%, $n=36)$, Aphaenogaster subterraneae $(0.1 \%, n=2)$, Lasius alienus $(0.1 \%, n=2)$ and Ponera coerctata $(<0.1 \%, n=1)$ were all relatively rare. The nest density of the more common ant species in the different habitat types is given in Appendix 3.

The 442 nests belonging to Solenopsis fugax were excluded from further modelling procedures because this tiny ant is not part of the Wryneck's diet (Freitag 1998).

\section{Modelling detection probability}

Temperature was the main factor influencing ant nest detection probability, followed by the amount of bare ground. Vegetation height had hardly an effect (Table 1). Detection probability increased with increasing temperature and amount of bare ground. Since vegetation height was not important, we estimated detection probability $\left(\hat{p}_{T, b}\right)$ using only the parameter estimates of temperature and bare ground $\left(\operatorname{logit}\left(\hat{p}_{T, b}\right)=0.3749+0.1605 * T+\right.$ $0.0771 * b)$.

\section{Relationship between ant abundance and environmental variables}

According to the AIC ranking, ant nest density was best explained by the model including amount of bare ground, habitat type and presence/absence of Wrynecks in the territory (Table 2). Uncertainty existed whether or not the interaction of habitat and bare ground should be included. 
Table 1 Model selection of ant nest detection probability using the Poisson mixture model from 36 plots with 3 sample occasions

\begin{tabular}{lclll}
\hline Model & $\Delta$ AIC & $\begin{array}{l}\text { AIC } \\
\text { weight }\end{array}$ & Deviance & $K$ \\
\hline $\mathrm{T}$ & 0.000 & 0.337 & 366.81 & 3 \\
$\mathrm{~T}+$ bare ground & 0.790 & 0.227 & 365.60 & 4 \\
$\mathrm{~T}+$ vegetation height & 1.990 & 0.125 & 366.80 & 4 \\
$\mathrm{~T}+$ vegetation height + bare & 2.450 & 0.099 & 365.26 & 5 \\
$\quad$ ground & & & & \\
Constant model & 2.570 & 0.093 & 371.38 & 2 \\
Bare ground & 3.410 & 0.061 & 370.22 & 3 \\
Vegetation height & 4.550 & 0.035 & 371.36 & 3 \\
Vegetation height + bare ground & 5.310 & 0.024 & 370.12 & 4 \\
\hline
\end{tabular}

The models refer to the detection probability only, for the abundance always a constant was used. Given are the $\Delta \mathrm{AIC}\left[\Delta \mathrm{AIC}_{i}=\mathrm{AIC}_{i}-\right.$ $\min (\mathrm{AIC})]$, the AIC weight $\left[w_{i}=\exp \left(-0.5 \times \Delta \mathrm{AIC}_{i}\right) / \Sigma \exp (-0.5 \times\right.$ $\triangle \mathrm{AIC})]$, the model deviance and the number of estimated parameters $(K)$. The models are ranked according to $\triangle \mathrm{AIC}$.

$T$ Ambient temperature

However, a comparison of model predictions with and without interaction revealed very similar results. According to the principle of parsimony, we therefore considered the model without interaction for inference. Ant nest density decreased with increasing amount of bare ground and was highest in semi-vegetated vineyards, followed by fruit tree plantations, pastures and meadows (Fig. 2). In all habitat types, ant nest density was higher at sites occupied by Wrynecks than at unoccupied sites. The best model for ant nest density extrapolation included amount of bare ground and habitat type with similar conclusions as above (Table 2).

Modelling of ant nest density in the different meadow types showed that ant nest density was lower in meadows characterised by more intensive management (Fig. 2). When bare ground amounted to $40 \%$, ant density in meadows with lowest farming intensity was 1.25 nests $/ \mathrm{m}^{2}$, while in the meadows with the highest farming intensity it was only 0.12 nests $/ \mathrm{m}^{2}$.

Variations of ant nest sizes were best explained by a quadratic effect of temperature, the amount of bare ground and habitat type (Table 3). The recorded ant nest size increased non-linearly with temperature and linearly with amount of bare ground (Fig. 3). The largest nests occurred in semi-vegetated vineyards and the smallest in pastures.

The proportion of nests containing brood (winged breeding imagos, worker larvae, sexuate larvae, worker pupae, sexuate pupae) increased strongly with increasing nest size (Fig. 4).

Table 2 Results of ant nest density modelling with a mixed model fitting a Poisson error distribution and using the counts corrected for detection probability ( $n=1,020$ plots)

\begin{tabular}{|c|c|c|c|c|}
\hline Model & $\Delta \mathrm{AIC}$ & AIC weight & Deviance & $K$ \\
\hline Bare ground + habitat + Wryneck presence & 0.000 & 0.322 & 1319.244 & 8 \\
\hline Bare ground + habitat + Wryneck presence + bare ground $\times$ habitat & 0.719 & 0.225 & 1313.963 & 11 \\
\hline Bare ground + bare ground ${ }^{2}+$ habitat + Wryneck presence & 1.736 & 0.135 & 1318.980 & 9 \\
\hline Bare ground + bare ground ${ }^{2}+$ habitat + Wryneck presence + bare ground $\times$ habitat & 2.695 & 0.084 & 1313.939 & 12 \\
\hline Bare ground + habitat $^{\mathrm{a}}$ & 2.762 & 0.081 & 1324.005 & r \\
\hline Bare ground + habitat + bare ground $\times$ habitat $^{\mathrm{a}}$ & 3.740 & 0.050 & 1318.984 & 10 \\
\hline Bare ground + habitat + Wryneck presence + habitat $\times$ Wryneck presence & 4.344 & 0.037 & 1317.587 & 11 \\
\hline Bare ground + bare ground ${ }^{2}+$ habitat $^{\mathrm{a}}$ & 4.748 & 0.030 & 1323.992 & 8 \\
\hline Bare ground + bare ground ${ }^{2}+$ habitat + Wryneck presence + habitat $\times$ Wryneck presence & 5.701 & 0.019 & 1318.945 & 11 \\
\hline Bare ground + bare ground ${ }^{2}+$ habitat + bare ground $\times$ habitat $^{\mathrm{a}}$ & 6.210 & 0.014 & 1317.454 & 12 \\
\hline Habitat + Wryneck presence & 8.917 & 0.004 & 1330.160 & 7 \\
\hline Habitat $^{\mathrm{a}}$ & 12.571 & 0.001 & 1335.814 & 0 \\
\hline Habitat + Wryneck presence + habitat $\times$ Wryneck presence & 13.241 & 0.000 & 1328.485 & 10 \\
\hline Wryneck presence & 65.687 & 0.000 & 1392.931 & 4 \\
\hline Bare ground + Wryneck presence & 67.672 & 0.000 & 1392.916 & 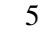 \\
\hline Bare ground + bare ground ${ }^{2}+$ Wryneck presence & 68.975 & 0.000 & 1392.219 & 0 \\
\hline Constant model ${ }^{\mathrm{a}}$ & 82.860 & 0.000 & 1412.104 & 3 \\
\hline Bare ground + bare ground ${ }^{2}$ a & 83.096 & 0.000 & 1408.340 & 5 \\
\hline Bare ground ${ }^{\mathrm{a}}$ & 83.218 & 0.000 & 1410.462 & 4 \\
\hline
\end{tabular}

The models are ranked according $\triangle$ AIC. For column headings see Table 1

a The 8 candidate models for ant density extrapolation 

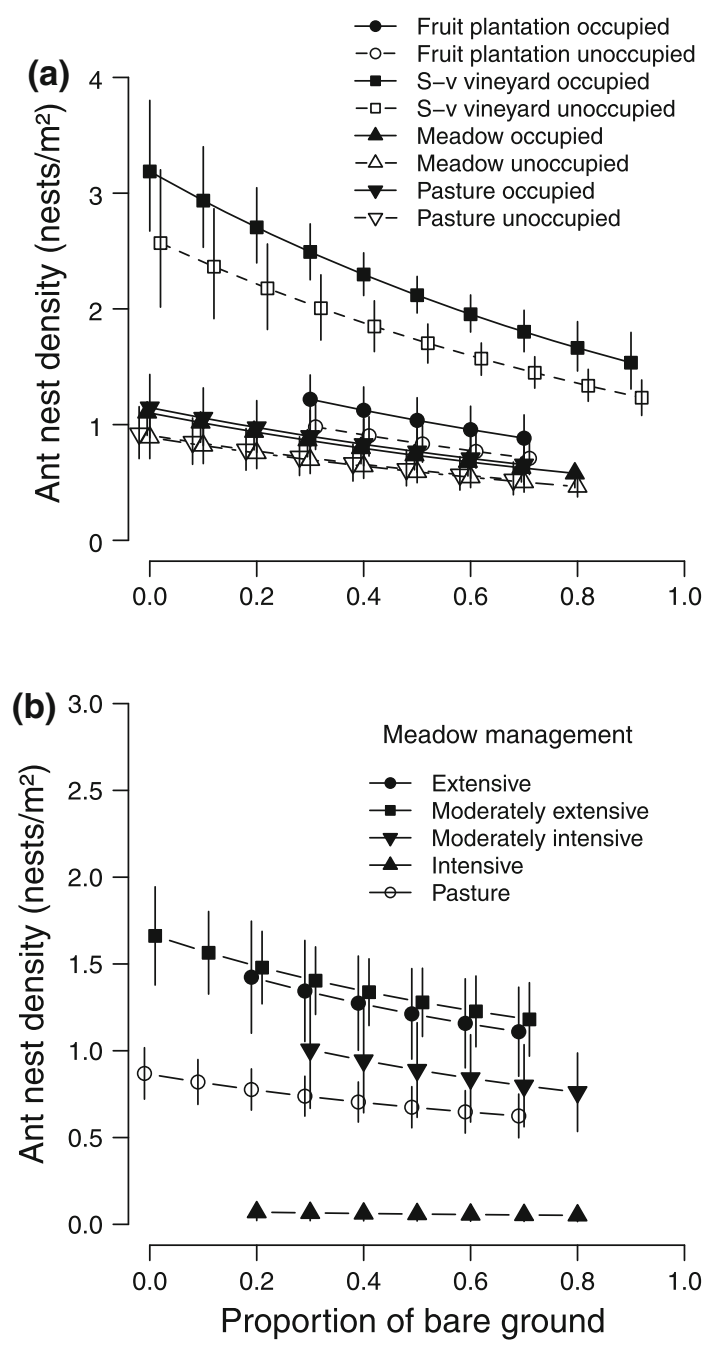

Fig. 2 Model-averaged ant nest density in relation a to proportion of bare ground in different habitat types that are occupied and unoccupied by Wrynecks, and $\mathbf{b}$ to proportion of bare ground for meadows managed at different intensities. Vertical lines standard errors. $S$ - $v$ semi-vegetated. The categories of meadow management are described in Appendix 1

\section{Habitat requirements of Wrynecks}

From the modelling of the structural variables, seven models were closely top-ranked $(\triangle \mathrm{AIC}<2)$ (Table 4$)$. The best models contained all considered variables, suggesting that all were potentially important. The probability that a territory was occupied by a Wryneck was much higher when at least one nestbox was present [probability of territory occupancy (mean $\pm \mathrm{SE}$ ); without nestboxes: $0.203 \pm 0.043$, with nestboxes: $0.949 \pm 0.059]$. It increased with increasing ant nest density and with increasing number of large trees (Fig. 5). The highest territory occupancy was achieved when the amount of bare ground was about 50\%. Territory was only marginally affected by edge length and habitat heterogeneity (Fig. 5).
The modelling of the habitat type variables resulted in five models with $\triangle \mathrm{AIC}<2$ (Table 5). These models contained all habitat types, suggesting that all were important for territory occupancy. Model-averaged effects sizes showed that territory occupancy probability was negatively related with the proportion of crop, meadow, pasture, and lawns (Fig. 6). Fruit tree plantations had a slightly positive effect while both vineyard types hardly had an effect.

\section{Discussion}

Our study revealed clear differences in structural variables and habitat types between occupied and unoccupied Wryneck territories. Occupied Wryneck territories were characterised by the presence of nestboxes, high number of large trees and high ant nest abundance, as well as by an amount of bare ground around 50\%. This suggests that any reduction in nesting sites, food abundance and its access is likely to contribute to the decline of Wryneck populations. Both ant abundance and accessibility were influenced by the amount of bare ground, indicating that the ground vegetation structure is a key element in the Wryneck habitat. This confirms former studies of fine-grained foraging habitat selection in another area of Switzerland (Weisshaupt 2007).

\section{Ant abundance}

Ant nest density decreased while ant nest size slightly increased with increasing amount of bare ground. Although invertebrate abundance generally increases with vegetation height (Morris 2000), the former observed relationship contradicts this view and our initial hypothesis, that surfaces well-exposed to the sun such as bare ground are important for ant brood development, which would lead to higher ant occurrence in bare soil areas (Kaspari 2000; Lessard and Buddle 2005; Platner 2006). Actually, the need for vegetation in nest vicinity as a source of food may overrule the thermal needs for colony development. In contrast, ant nest density declined with intensifying grassland management, which gives a more pronounced sward cover. This suggests that an optimal vegetation cover for ants exists, which results from a trade-off between trophic and eco-physiological requirements. A larger ant nest size at high ambient temperature and in the presence of extensive bare ground indicates that ants move deeper into the soil as soon as bad weather or dense sward cool the soil surface (Talbot 1946; Freitag et al. 2001).

Particularly high ant nest densities were recorded in semi-vegetated vineyards. This contrasts with another viticultural region of Switzerland (Valais) where ant nest density was low in vineyards, a habitat type avoided by 
Table 3 Results of ant nest size modelling using a mixed model with normal error distribution $(n=1,647$ nests $)$
The models are ranked according to $\triangle$ AIC. For column headings see Table 1

$T$ Ambient temperature

\begin{tabular}{|c|c|c|c|c|}
\hline Model & $\Delta \mathrm{AIC}$ & AIC weight & Deviance & $K$ \\
\hline Habitat $+T+T^{2}$ & 0.000 & 0.409 & $14,209.067$ & 9 \\
\hline Habitat $+T^{2}$ & 0.809 & 0.273 & $14,204.079$ & 8 \\
\hline Bare ground + habitat $+T$ & 1.773 & 0.168 & $14,207.164$ & 9 \\
\hline Bare ground + habitat $+T+T^{2}$ & 2.024 & 0.149 & $14,214.244$ & 10 \\
\hline Bare ground + bare ground ${ }^{2}+$ habitat $+T+T^{2}$ & 11.935 & 0.001 & $14,199.674$ & 11 \\
\hline Bare ground + bare ground ${ }^{2}+$ habitat $+T$ & 13.933 & 0.000 & $14,204.117$ & 10 \\
\hline Bare ground + habitat & 21.413 & 0.000 & $14,225.051$ & 8 \\
\hline Habitat & 26.589 & 0.000 & $14,237.647$ & 7 \\
\hline Bare ground $+T$ & 31.890 & 0.000 & $14,222.243$ & 5 \\
\hline Bare ground $+T+T^{2}$ & 33.117 & 0.000 & $14,228.136$ & 6 \\
\hline Bare ground + bare ground ${ }^{2}+$ habitat & 33.222 & 0.000 & $14,228.983$ & 9 \\
\hline Bare ground + bare ground ${ }^{2}+T$ & 41.568 & 0.000 & $14,245.231$ & 4 \\
\hline$T+T^{2}$ & 42.625 & 0.000 & $14,247.414$ & 5 \\
\hline Bare ground + bare ground ${ }^{2}+T+T^{2}$ & 44.770 & 0.000 & $14,243.009$ & 6 \\
\hline Bare ground & 47.704 & 0.000 & $14,228.995$ & 4 \\
\hline$T^{2}$ & 47.795 & 0.000 & $14,228.157$ & 7 \\
\hline Bare ground + bare ground ${ }^{2}$ & 61.286 & 0.000 & $14,243.010$ & 5 \\
\hline Constant model & 64.221 & 0.000 & $14,266.910$ & 3 \\
\hline
\end{tabular}

(a)

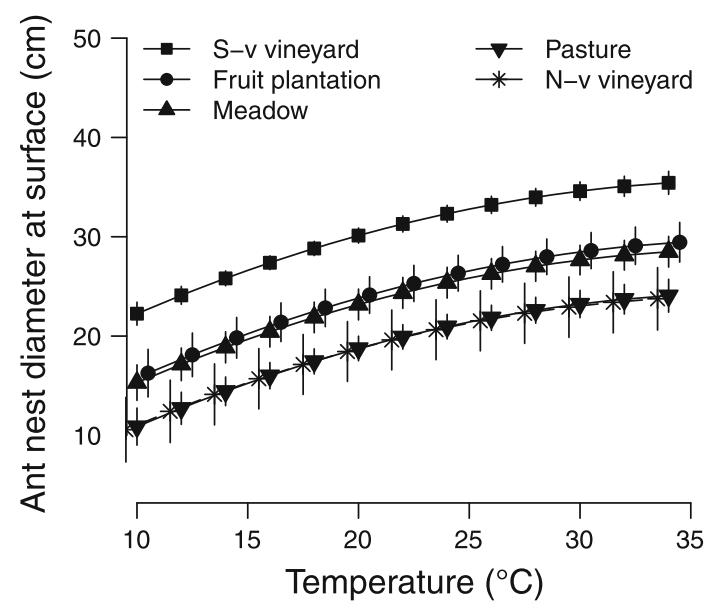

(b)

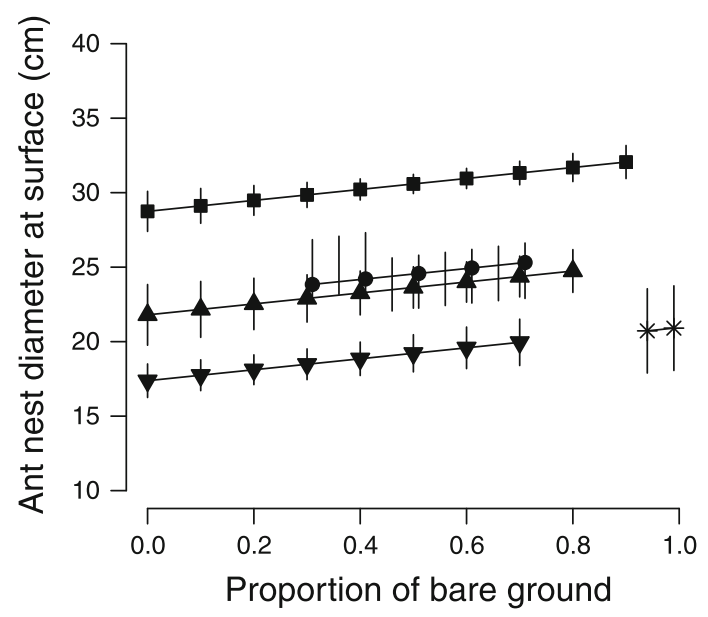

Fig. 3 Model-averaged ant nest diameter in relation to a temperature and $\mathbf{b}$ amount of bare ground for different habitat types. Vertical lines standard errors. $S$ - $v$ semi-vegetated, $N-v$ non-vegetated

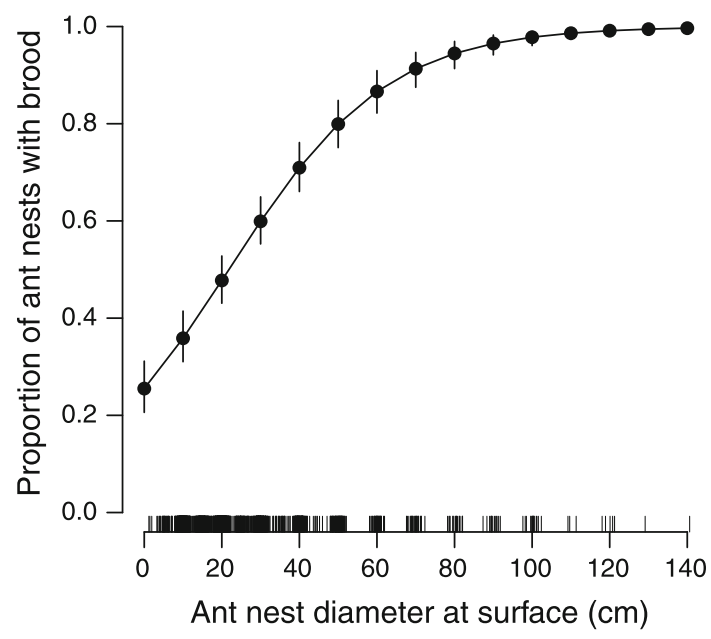

Fig. 4 Proportion of ant nests containing a brood in relation to nest size. Vertical lines standard errors

local Wrynecks (Freitag 1998; Mermod et al. 2009). We see two reasons for this apparent geographic discrepancy. First, soils are much more mineral (stony) in Valais. Second, vineyards in Valais are still scarcely vegetated $(<5 \%$ of the total area), offering very little room for thriving ant populations. Vineyards and fruit tree plantations thus represent suitable Wryneck habitat only if they are planted in soft substrates and harbour a mix of vegetated and bare strips under the vine and tree rows.

Ant abundance was low in meadows and pastures compared to vineyards. However, ant nest densities differed according to the intensity of meadow management, with highly fertilised meadows containing much lower ant nest densities. Factors affecting ants in intensively managed meadow have been little studied, yet our results 
Table 4 Modelling results of the Wryneck territory occupancy probability in relation to structural variables using mixed models with a binomial error distribution ( $n=154$ sites)

\begin{tabular}{|c|c|c|c|c|}
\hline Model & $\Delta \mathrm{AIC}$ & AIC weight & Deviance & $K$ \\
\hline Nestbox + trees + edge + ants + bare ground + bare ground $^{2}$ & 0.000 & 0.137 & 126.591 & 8 \\
\hline Nestbox + trees + ants + bare ground + bare ground ${ }^{2}$ & 0.158 & 0.127 & 128.750 & 7 \\
\hline Nestbox + edge + ants + bare ground + bare ground ${ }^{2}$ & 1.607 & 0.062 & 130.199 & 7 \\
\hline Nestbox + trees + edge + ants & 1.612 & 0.061 & 132.204 & 6 \\
\hline Nestbox + ants + bare ground + bare ground ${ }^{2}$ & 1.766 & 0.057 & 132.358 & 6 \\
\hline Nestbox + trees + edge + ants + bare ground + bare ground $^{2}+$ heterogeneity & 1.787 & 0.056 & 126.379 & 9 \\
\hline Nestbox + trees + ants + bare ground + bare ground ${ }^{2}+$ heterogeneity & 1.818 & 0.055 & 128.409 & 8 \\
\hline Nestbox + ants + bare ground + bare ground ${ }^{2}+$ heterogeneity & 2.109 & 0.048 & 130.700 & 7 \\
\hline Nestbox + edge + ants & 2.199 & 0.046 & 134.791 & 5 \\
\hline Nestbox + edge + ants + bare ground + bare ground ${ }^{2}+$ heterogeneity & 2.212 & 0.045 & 128.804 & 8 \\
\hline Nestbox + edge + ants + heterogeneity & 2.868 & 0.033 & 133.459 & 6 \\
\hline Nestbox + bare ground + bare ground ${ }^{2}+$ heterogeneity & 3.026 & 0.030 & 133.617 & 6 \\
\hline Nestbox + edge + bare ground + bare ground ${ }^{2}+$ heterogeneity & 3.081 & 0.029 & 131.673 & 7 \\
\hline Nestbox + trees + edge + ants + heterogeneity & 3.212 & 0.028 & 131.804 & 7 \\
\hline Nestbox + ants & 3.622 & 0.022 & 138.213 & 4 \\
\hline Nestbox + edge + bare ground + bare ground ${ }^{2}+$ heterogeneity & 3.825 & 0.020 & 130.416 & 8 \\
\hline Nestbox + trees + bare ground + bare ground ${ }^{2}+$ heterogeneity & 3.855 & 0.020 & 132.446 & 7 \\
\hline Nestbox + trees + ants & 3.911 & 0.019 & 136.502 & 5 \\
\hline Nestbox + ants + heterogeneity & 3.962 & 0.019 & 136.553 & 5 \\
\hline
\end{tabular}

Models are ranked according to $\triangle \mathrm{AIC}$, and those that accumulate AIC weights of 0.9 are presented. For column headings see Table 1

indicate that extensification of meadow management (i.e., reduction of fertiliser application) would increase ant abundance (Folgarait 1998; Underwood and Fischer 2006).

The ant community was dominated by four species, Lasius niger, L. flavus, Tetramorium caespitum, and Solenopsis fugax. These ant species are common prey of Wrynecks, with the exception of the tiny Solenopsis fugax which was not considered in our analyses (Bitz and Rohe 1993; Freitag 1998; Ehrenbold 2004; Kervyn and Xhardez 2006). The habitat which offered good conditions for all species considered was semi-vegetated vineyards. The existence of diverse ant communities may be important for Wrynecks provisioning chicks with ant eggs and pupae, because ant species differing in their breeding phenology (Freitag 1998) may provide long-lasting and abundant food supplies.

Is the number of breeding cavities a limiting factor?

Wrynecks clearly preferred territories containing nestboxes and a high number of large trees, suggesting that a lack or reduction of breeding sites may limit Wryneck distribution. This can be understood because woodpeckers typically need more than one cavity per territory (Cramp 1985; Bull et al. 1992). The importance of suitable nesting cavities for Wrynecks has also recently been confirmed experimentally: the probability of territory occupancy increases with the number of adequate nestboxes supplied (Zingg et al. 2010).

Is ant abundance a limiting factor?

The probability that a territory is occupied by Wrynecks increased with increasing ant nest density, suggesting that ant abundance has an impact on Wryneck populations. Wrynecks also avoided habitat types that had low ant nest densities such as crop, meadows and pastures. While the avoidance of meadows and pastures might also result from a reduced accessibility (see below), this is unlikely to be true for crop, where access to ants is not permanently hampered by vegetation.

Meadows and pastures farmed at low intensity in combination with trees (orchards) have historically constituted the favourite habitat of Central European Wrynecks (Hölzinger 1987; Cramp 1985). Yet, the traditional management of grassland in orchards has vanished since World War II, being progressively replaced by heavily fertilised meadows and intensively grazed pastures. This may explain why Wrynecks are today so rare in what constituted their key habitat in the past. Restoring Wryneck populations in grassland dominated landscapes thus seems only possible if the input of fertilisers is massively reduced. 
Fig. 5 Model-averaged occupancy probability of Wryneck territories in relation to $\mathbf{a}$ ant nest density, $\mathbf{b}$ forest edge and hedge length, c number of large trees, d habitat heterogeneity and eproportion of bare ground for territories without nestboxes (broken lines) and with nestboxes (solid lines). Dotted lines standard errors
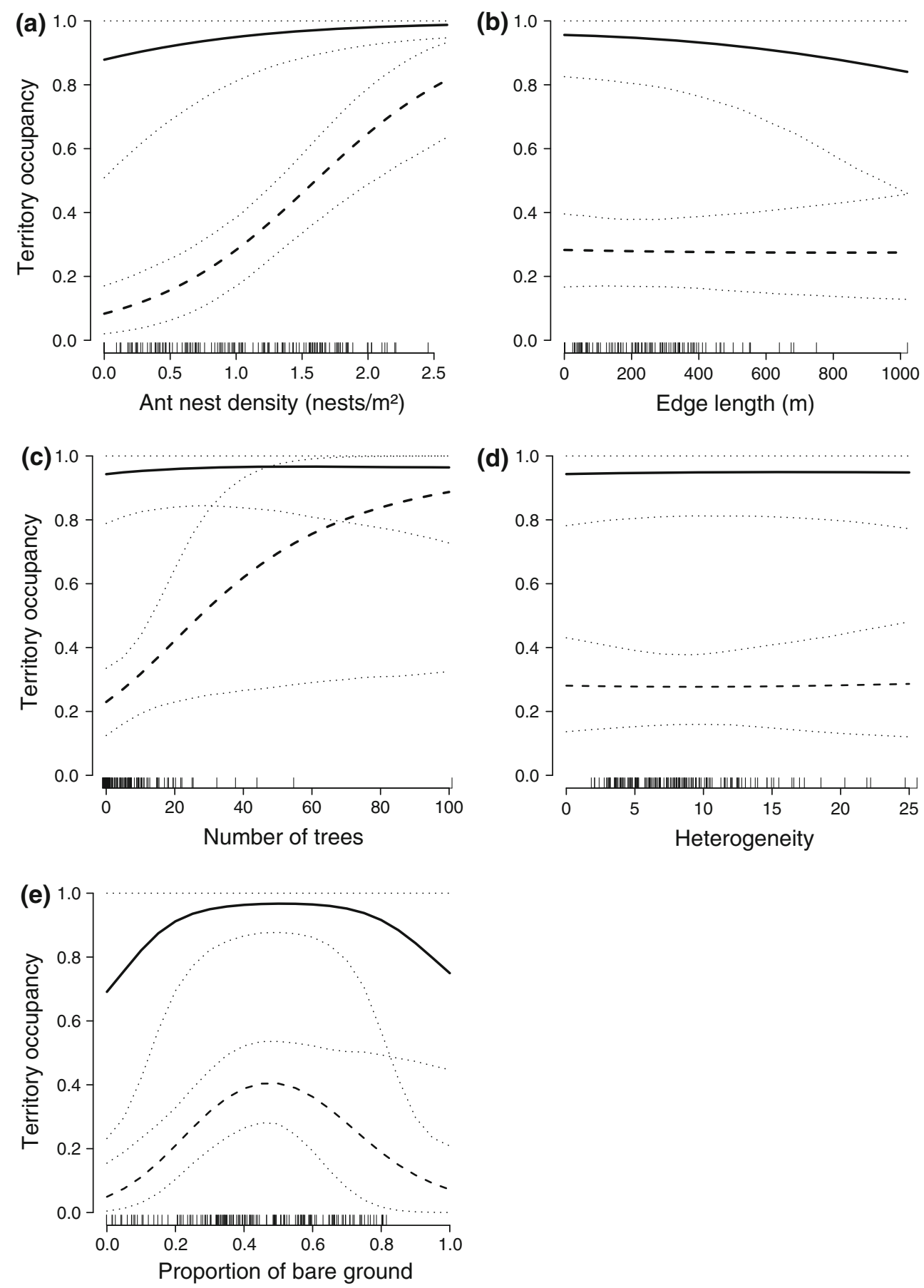

Ant nest densities were consistently higher in territories occupied by Wrynecks, regardless of the habitat type. This suggests that Wrynecks appraise territory quality by directly estimating ant nest densities.

Could a change in vegetation structure reduce access to or detectability of food resources for Wrynecks?

Territories with ca $50 \%$ of bare ground were preferred over territories offering less or more bare ground area. This observation is in line with a recent radiotracking study that established that Wrynecks forage mainly at locations with more than about $60 \%$ of bare ground (Weisshaupt 2007). Theoretically, the accessibility of ant nests should increase linearly with increasing amount of bare ground. However, because ant nest density declines with increasing amount of bare ground, the preference for a medium amount of bare ground appears to be the result of a trade-off between food abundance and food accessibility. Thus, the vegetation structure is important for the accessibility to ants for 
Table 5 Modelling results of Wryneck territory occupancy probability in relation to habitat type variables using a mixed model with binomial error distribution ( $n=154$ sites)

\begin{tabular}{|c|c|c|c|}
\hline Model & $\Delta \mathrm{AIC}$ & AIC weight & Deviance \\
\hline Meadow + pasture + lawn + crop & 0.000 & 0.200 & 172.586 \\
\hline Meadow + pasture + lawn + fruit tree plantations + crop & 0.999 & 0.121 & 171.586 \\
\hline Crop + meadow + lawn & 1.630 & 0.088 & 176.216 \\
\hline Meadow + pasture + lawn + non-vegetated vineyard + crop & 1.709 & 0.085 & 172.295 \\
\hline Meadow + pasture + lawn + semi-vegetated vineyard + crop & 1.788 & 0.082 & 172.374 \\
\hline Meadow + pasture + lawn + fruit tree plantations + non-vegetated vineyard + crop & 2.802 & 0.049 & 171.388 \\
\hline Meadow + pasture + lawn + fruit tree plantations + semi-vegetated vineyard + crop & 2.994 & 0.045 & 171.580 \\
\hline Meadow + pasture + lawn + non-vegetated vineyard + semi-vegetated vineyard + crop & 3.463 & 0.035 & 172.049 \\
\hline Crop + meadow + pasture & 3.369 & 0.037 & 177.955 \\
\hline Crop + meadow + fruit tree plantations & 4.019 & 0.027 & 178.605 \\
\hline Fruit tree plantation + semi-vegetated vineyard & 4.162 & 0.025 & 180.749 \\
\hline Crop + meadow & 4.239 & 0.024 & 180.826 \\
\hline Crop + fruit tree plantations + semi-vegetated vineyard & 4.524 & 0.021 & 179.110 \\
\hline Meadow + pasture + lawn + fruit tree plantations + non-vegetated vineyard + semi-vegetated vineyard + crop & 4.786 & 0.018 & 171.372 \\
\hline Meadow + fruit tree plantations + semi-vegetated vineyard & 5.015 & 0.016 & 179.602 \\
\hline Crop + meadow + semi-vegetated vineyard & 5.204 & 0.015 & 179.791 \\
\hline Crop + fruit tree plantation + lawn + semi-vegetated vineyard & 5.537 & 0.013 & 178.123 \\
\hline Meadow + lawn + fruit tree plantations + non-vegetated vineyard + semi-vegetated vineyard + crop & 5.578 & 0.012 & 174.164 \\
\hline Fruit tree plantation + lawn + semi-vegetated vineyard & 5.793 & 0.011 & 180.379 \\
\hline Pasture + fruit tree plantations + semi-vegetated vineyard & 5.897 & 0.010 & 180.483 \\
\hline Crop + pasture + fruit tree plantations + semi-vegetated vineyard & 5.933 & 0.010 & 178.520 \\
\hline Meadow + fruit tree plantations + non-vegetated vineyard + semi-vegetated vineyard + crop & 5.980 & 0.010 & 176.566 \\
\hline Fruit tree plantations + semi-vegetated vineyard + non-vegetated vineyard & 6.068 & 0.010 & 180.655 \\
\hline Crop + meadow + non-vegetated vineyard & 6.193 & 0.009 & 180.779 \\
\hline Crop + fruit tree plantations + semi-vegetated vineyard + non-vegetated vineyard & 6.519 & 0.008 & 179.105 \\
\hline Crop + pasture + fruit tree plantations + lawn + semi-vegetated vineyard & 6.605 & 0.007 & 177.191 \\
\hline Meadow + pasture + fruit tree plantations + non-vegetated vineyard + semi-vegetated vineyard + crop & 6.690 & 0.007 & 175.276 \\
\hline Crop + pasture + fruit tree plantations + lawn & 7.179 & 0.006 & 179.765 \\
\hline
\end{tabular}

Models are ranked according to $\triangle \mathrm{AIC}$, and those that accumulate AIC weights of 0.9 are presented. For column headings see Table 1

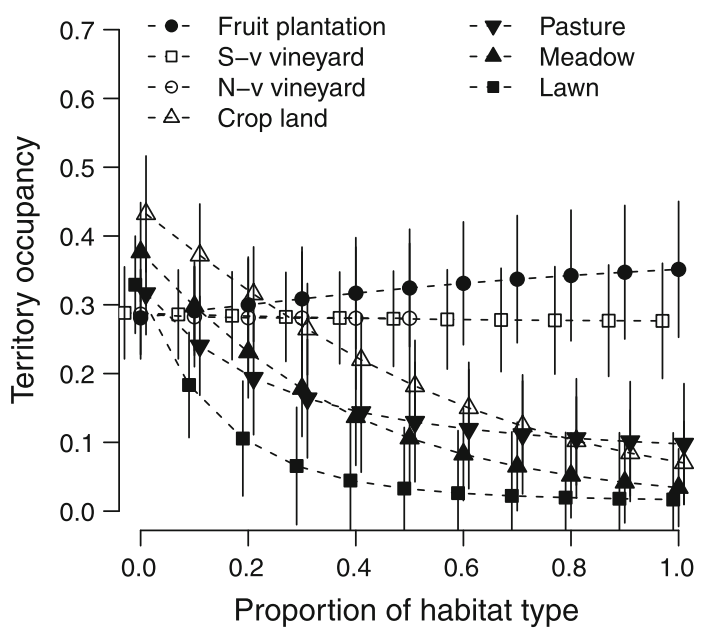

Fig. 6 Model-averaged occupancy probability of Wryneck territories in relation to different habitat types. Vertical lines standard errors. $S$-v semi-vegetated, $N$ - $v$ non-vegetated
Wrynecks, and the change of the vegetation structure due to increased fertiliser application has probably massively contributed to its decline.

\section{Conservation implications}

Our results demonstrate that breeding opportunities, ant abundance and accessibility were very important factors limiting the distribution of Wrynecks. Wrynecks did not show clear preferences for particular habitat types, and appear flexible as regards habitat choice insofar as semiopen landscapes are present. Hence, suitable nesting cavities as well as ant-rich, open ground vegetation structures for foraging are key elements for the persistence of Wryneck populations. Nesting cavities can naturally occur at sufficient density where old trees remain numerous; alternatively, nestboxes can be provided (Zingg et al. 2010). In 
semi-open grassland-dominated matrices, meadows must be managed at low intensity such that the vegetation structure becomes more open, with the intention both to boost ant abundance and to facilitate accessibility to prey for Wrynecks. In vineyards and fruit tree plantations, management practices must promote a mix of bare and vegetated surfaces. Semi-open landscapes with a mix of bare and vegetated ground surfaces have been proven essential for many other ground-foraging species (Benton et al. 2003; Atkinson et al. 2004; Butler and Gillings 2004; Martinez et al. 2010) and will benefit many other elements of flora and fauna.

\section{Zusammenfassung}

Nahrung oder Nistplätze? Bestimmung von limitierenden Faktoren in Wendehalspopulationen

In den letzten Jahrzehnten haben viele Vogelpopulationen als Folge der Intensivierung der Landwirtschaft markant abgenommen. Die genauen Mechanismen, die zum Rückgang geführt haben, sind aber nicht immer klar. So könnte der in Höhlen brütende und auf Ameisennahrung spezialisierte Wendehals Jynx torquilla sowohl durch eine Verminderung der Nistplätze, der Nahrungsmenge oder deren Verfügbarkeit limitiert werden. Um die relative Wichtigkeit dieser Faktoren zu bestimmen, verglichen wir in der Westschweiz besetzte Wendehalsreviere mit zufällig ausgewählten Orten, an denen keine Wendehälse vorkamen (Zufallsreviere; total 154 Reviere). Wir untersuchten auch
Umweltfaktoren, die einen Einfluss auf die Dichte der Wiesenameisen hatten. Die Wahrscheinlichkeit, dass ein Revier von einem Wendehals besetzt war, stieg mit der Anzahl vorhandener Nistkästen und der Dichte an Ameisennester an. Ausserdem wurden Reviere bevorzugt, die etwa 50\% offener Boden aufwiesen. Habitattypen, die eine geringe Dichte an Ameisennestern hatten, wie Ackerland und intensives Grünland, wurden gemieden. Die Dichte der Ameisennester nahm mit zunehmender Vegetationsdichte $\mathrm{zu}$, und sie war am höchsten in Reben. Unsere Resultate zeigen, dass sowohl Brutplätze, Nahrung, wie auch der Zugang zur Nahrung (offener Boden) limitierende Faktoren für die Verbreitung der Wendehälse sind. Grünland mit einer hohen Dichte an Wiesenameisennestern, das mosaikartig verteilt vegetationslose Stellen und in unmittelbarer Umgebung Bäumen mit Höhlen oder Nistkästen aufweist, scheinen die wichtigsten Faktoren zu sein, um Wendehalspopulationen erhalten und fördern zu können. Diese Eigenschaften können in unterschiedlichen Habitattypen vorhanden sein, sogar in intensiv genutzten Habitaten wie Obstanlagen oder Reben.

Acknowledgments Data on Wryneck breeding sites were kindly provided by Hans Schmid, Niklaus Zbinden, Blaise Mulhauser, Sébastien Chabot, Bernard Genton, Bernard Lugrin and Michel Rogg. We thank Fitsum Abadi Gebreselassie for statistical advise, Jerôme Guelat for his help with GIS, and Niklaus Zbinden for valuable comments. Diane Patry offered accommodation during the field work.

\section{Appendix 1}

See Table 6.

Table 6 Variables considered to model Wryneck territory occupancy

\begin{tabular}{|c|c|c|}
\hline Category & Variables & Description \\
\hline \multirow[t]{7}{*}{ Habitat types } & Fruit plantation & Intensively cultivated small fruit trees in lines \\
\hline & Non-vegetated vineyard & Vineyard with $<5 \%$ vegetation on the ground \\
\hline & Semi-vegetated vineyard & Vineyard with $5-90 \%$ vegetation cover on the ground \\
\hline & Meadow & 4 categories of management (I1-I4, see below) \\
\hline & Lawn & \\
\hline & Pasture & \\
\hline & Crop & Crop, maize, rape, vegetables \\
\hline \multirow[t]{5}{*}{ Structural variables } & Edge & Total length of hedges and forest border \\
\hline & Bare ground & Proportion of visible bare ground when looking vertically from above \\
\hline & Large trees & Number of trees with a diameter larger than $15 \mathrm{~cm}$ \\
\hline & Nestboxes & Presence of at least one nest box within the site \\
\hline & Heterogeneity & Number of parcels within a territory \\
\hline
\end{tabular}

Types of meadow management: I1, extensive meadows with one or two cuts pro year; I2, extensive meadows with two to three cuts per year. The vegetation is dominated by Arrhenatherum elatius; I3, moderately intensive meadows with several cuts per years. The vegetation is dominated by Dactylis glomerata; I4, Intensively fertilised meadows with several cuts per years. The vegetation is dominated by Lolium perenne 


\section{Appendix 2}

See Table 7.

Table 7 Number of habitat type parcels where ant nests were sampled

\begin{tabular}{|c|c|c|c|c|}
\hline Region & Habitat type & Occupied & Unoccupied & Total \\
\hline \multirow[t]{7}{*}{ Neuchâtel } & Crop & 2 & 8 & 10 \\
\hline & Meadow & 9 & 12 & 21 \\
\hline & Fruit tree plantation & 0 & 0 & 0 \\
\hline & Pasture & 7 & 7 & 14 \\
\hline & Non-vegetated vineyard & 2 & 0 & 2 \\
\hline & Semi-vegetated vineyard & 32 & 0 & 32 \\
\hline & Total Neuchâtel & 52 & 27 & 79 \\
\hline \multirow[t]{7}{*}{ La Côte } & Crop & 1 & 6 & 7 \\
\hline & Meadow & 0 & 9 & 9 \\
\hline & Fruit tree plantation & 11 & 12 & 23 \\
\hline & Pasture & 2 & 4 & 6 \\
\hline & Non-vegetated vineyard & 1 & 0 & 1 \\
\hline & Semi-vegetated vineyard & 24 & 20 & 44 \\
\hline & Total La Côte & 39 & 51 & 90 \\
\hline \multirow[t]{7}{*}{ Geneva } & Crop & 3 & 8 & 11 \\
\hline & Meadow & 5 & 11 & 16 \\
\hline & Fruit tree plantation & 0 & 0 & 0 \\
\hline & Pasture & 0 & 1 & 1 \\
\hline & Non-vegetated vineyard & 0 & 0 & 0 \\
\hline & Semi-vegetated vineyard & 6 & 32 & 38 \\
\hline & Total Geneva & 14 & 52 & 66 \\
\hline $\begin{array}{l}\text { Total } \\
\text { overall }\end{array}$ & & 105 & 130 & 235 \\
\hline
\end{tabular}

\section{Appendix 3}

See Fig. 7.

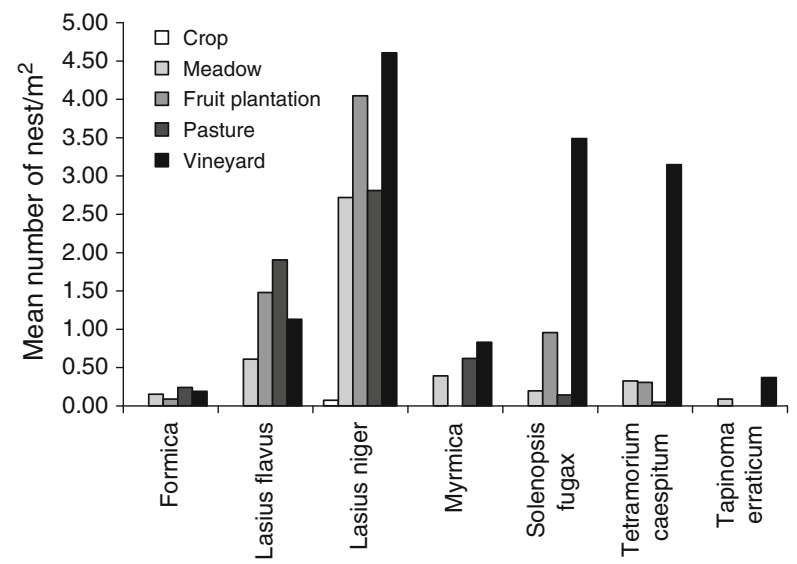

Fig. 7 Nest density of the most common ant species in different habitat types

\section{References}

Atkinson PW, Buckingham DL, Morris AJ (2004) What factors determine where invertebrate-feeding birds forage in dry agricultural grasslands? Ibis 146(Suppl 2):99-107

Benton TG, Bryant DM, Cole L, Crick HQP (2002) Linking agricultural practice to insect and bird populations: a historical study over three decades. J Appl Ecol 39:673-687

Benton TG, Vickery JA, Wilson JD (2003) Farmland biodiversity: is habitat heterogeneity the key? Trends Ecol Evol 18:182-188

Bestelmeyer BT, Wiens JA (2001) Ant biodiversity in semiarid landscape mosaics: the consequences of grazing vs. natural heterogeneity. Ecol Appl 11:1123-1140

Bitz A, Rohe W (1993) Nahrungsökologische Untersuchungen am Wendehals (Jynx torquilla) in Rheinland-Pfalz. Beih Veröff Naturschutz Landschaftspflege Bad-Württ 67:83-100

Blanco G, Tella JL, Torre I (1998) Traditional farming and key foraging habitats for chough Pyrrhocorax pyrrhocorax conservation in a Spanish pseudosteppe landscape. J Appl Ecol 35:232-239

Bromham L, Cardillo M, Bennett AF, Elgar MA (1999) Effects of stock grazing on the ground invertebrate fauna of woodland remnants. Aust J Ecol 24:199-207

Bull EL, Holthausen RS, Henjum MG (1992) Roost trees used by pileated woodpeckers in northeastern Oregon. J Wildl Manag 56:786-793

Burnham KP, Anderson DR (2002) Model selection and inference. Springer, New York

Butler SJ, Gillings S (2004) Quantifying the effects of habitat structure on prey detectability and accessibility to farmland birds. Ibis 146(Suppl 2):123-130

Cornelius C, Cockle K, Politi N, Berkunsky I, Sandoval L, Ojeda V, Rivera L, Hunter M Jr, Martin K (2008) Cavity-nesting birds in neotropical forests: cavities as a potentially limiting resource. Ornithol Neotrop 19:253-268

Cramp S (1985) The birds of the Western Palearctic, vol 4. Oxford University Press, Oxford

Della Santa E (1994) Guide pour l'identification des principales espèces de fourmis de Suisse. Centre suisse de cartographie de la faune, Neuchâtel

Donald PF, Green RE, Heath MF (2001) Agricultural intensification and the collapse of Europe's farmland bird populations. Proc R Soc Lond B 268:25-29

Ehrenbold S (2004) Habitat suitability modelling and components of reproductive success in the Wryneck Jynx torquilla. Diplomarbeit. Philosophisch-naturwissenschaftliche Fakultät der Universität Bern

Folgarait PJ (1998) Ant biodiversity and its relationship to ecosystem functioning: a review. Biodivers Conserv 7:1221-1244

Freeman KE, Kirk DA (2001) Birds on organic and conventional farms in Ontario: partitioning effects of habitat and practices on species composition and abundance. Biol Conserv 101:337-350

Freitag A (1996) Le régime alimentaire du Torcol fourmilier (Jynx torquilla) en Valais (Suisse). Nos Oiseaux 43:497-512

Freitag A (1998) Analyse de la disponibilité spatio-temporelle des fourmis et des strategies de fourragement du torcol fourmilier (Jynx torquilla L.). Thèse de Doctorat. Université de Lausanne

Freitag A, Martinoli A, Urzelai J (2001) Monitoring the feeding activity of nesting birds with an autonomous system: case study of the endangered Wryneck Jynx torquilla. Bird Study 48:102-109

Hines JE (2006) PRESENCE software to estimates patch occupancy rates and related parameters. Patuxent Wildlife Research Center, Laurel

Hölzinger J (1987) Wendehals—Jynx torquilla. Die Vögel BadenWürttembergs. Gefährdung und Schutz. Ulmer, Stuttgart, pp $1152-1156$ 
Hutto RL (1990) Measuring the availability of food resources. Stud Avian Biol 13:20-28

Kaspari M (2000) A primer on ant ecology. In: Agosti D, Majer J, Alonso L, Schultz TR (eds) Ants: Standard methods for measuring and monitoring biodiversity. Smithsonian Institution Press, Washington, DC

Kervyn T, Xhardez C (2006) Utilisation de l'espace par le Torcol fourmilier (Jynx torquilla) lors d'une nidification uniparentale en Ardenne. Aves 43:65-72

Lessard J-P, Buddle CM (2005) The effects of urbanization on ant assemblage (Hymenoptera: Formicidae) associated with the Molson Nature Reserve, Quebec. Can Entomol 137:215-225

Martinez N, Jenni L, Wyss E, Zbinden N (2010) Habitat structure versus food abundance: the importance of sparse vegetation for the common redstart Phoenicurus phoenicurus. J Ornithol 151:297-307

McCracken DI, Tallowin JR (2004) Swards and structure: the interactions between farming practices and bird food resources in lowland grasslands. Ibis 146(Suppl 2):108-114

Mermod M, Arlettaz R, Reichlin TS, Schaub M (2009) The importance of ant-rich habitats for the persistence of the Wryneck Jynx torquilla on farmland. Ibis 151:731-742

Morris MG (2000) The effects of structure and its dynamics on the ecology and conservation of arthropods in British grasslands. Biol Conserv 95:129-142

Newton I (2004) The recent declines of farmland bird populations in Britain: an appraisal of causal factors and conservation actions. Ibis 146:579-600

Peck SL, McQuaid K, Campbell CL (1998) Using ant species (Hymenoptera: Formicidae) as a biological indicator of agroecosystem condition. Environ Entomol 27:1102-1110
Platner C (2006) Ameisen als Schlüsseltiere in einem Grasland. Studien zu ihrer Bedeutung für die Tiergemeinschaft, das Nahrungsnetz und das Ökosystem. Universitätsverlag Göttingen

Poeplau N (2005) Untersuchungen zur Siedlungsdichte und Habitatqualität des Wendehalses (Jynx torquilla) in Südhessen. Zeitschrift für Vogelkunde und Naturschutz in Hessen. Vogel Umwelt 16:115-127

Royle JA, Nichols JD (2003) Estimating abundance from repeated presence-absence data or point counts. Ecology 84:777-790

Seifert B (1996) Ameisen. Naturbuch, Augsburg

Talbot M (1946) Daily fluctuations in aboveground activity of three species of ants. Ecology 27:65-70

Tomialojc L (1994) Wryneck. In: Tucker GM, Heath MF (eds) Birds in Europe: their conservation status. BirdLife International, Cambridge, pp 342-343

Underwood E, Fischer B (2006) The role of ants in conservation monitoring: if, when, and how. Biol Conserv 132:166-182

Weisshaupt N (2007) Habitat selection by foraging wrynecks Jynx torquilla during the breeding season: identifying optimal species habitat. Masterarbeit. Philosophisch-naturwissenschaftliche Fakultät der Universität Bern

Wilson JD, Whittingham MJ, Bradbury RB (2005) The management of crop structure: a general approach to reversing the impacts of agricultural intensification on birds? Ibis 147:453-463

Wretenberg J, Lindström A, Svensson S, Thierfelder T, Pärt T (2006) Population trends of farmland birds in Sweden and England: similar trends but different patterns of agricultural intensification. J Appl Ecol 43:1110-1120

Zingg S, Arlettaz R, Schaub M (2010) Nestbox design influences territory occupancy and reproduction in a declining, secondary cavity-breeding bird. Ardea 98:67-75 